\title{
Regulatory failures, split-incentives, conflicting interests and a vicious circle of blame: The New Environmental Governance to the rescue?
}

\begin{abstract}
This article addresses a current trend of new environmental governance (NEG). It examines whether NEG is able to overcome a series of complex regulatory barriers and market shortfalls that stand in the way of carbon emissions reductions in the building sector. Building on an evaluation of 20 NEG arrangements from Australia and the Netherlands, it discusses the limits of the effective implementation and use of NEG in this sector. The article concludes by suggesting three strategies to improve the performance of NEG arrangements.
\end{abstract}

\section{$1 \quad$ Introduction}

The shift from government to governance (Rhodes, 1997) is perhaps best visible in the area of environmental policy and governance (Jordan, Wurzel, \& Zito, 2005). There appears to be no limit to the range of innovative types of governance arrangements that scholars have been uncovering since the 1990s - e.g., Voluntary Environmental Programmes (Borck \& Coglianese, 2009), Non-State Market-Driven governance (Cashore, Auld, \& Newsom, 2004) and Collaborative Environmental Institutions (Lubell, 2004). A recent addition to the environmental governance literature is the New Environmental Governance, or NEG (Backstrand, Khan, Kronsell, \& Lovbrand, 2010; Hoffmann, 2011; Holley, Gunningham, \& Shearing, 2012). Broadly speaking, NEG includes the addressing of environmental risks by collaborations of governmental and non-governmental actors, often through non-mandatory approaches (NEG theorising is addressed in more depth in section 3). To date, NEG has achieved much acclaim for what it is potentially able to achieve in terms of effective and efficient environmental governance (De Búrca \& Scott, 2006; Sabel \& Zeitlin, 2012). An emerging empirical body of literature, however, is critical as to whether NEG is able to deliver on its normative expectations (Borck \& Coglianese, 2009; Gunningham, 2009; Koehler, 2007); and the effectiveness of NEG appears to be highly dependent on the design of NEG arrangements and the context they are implemented in (cf., Van der Heijden, 2012). Time and again, scholars stress the importance of systematic research into NEG to better understand when, where and how its outcomes are caused (Holley, et al., 2012; Wurzel, Zito, \& Jordan, 2013).

Such an understanding is of importance to policymakers and practitioners who seek to introduce NEG arrangements themselves. One of the sectors of much NEG activity is the 
building sector, in which NEG arrangements are introduced particularly to address the sector's significant contribution to global carbon emissions. As it accounts for over $30 \%$ of global carbon emissions, it is one of the most carbon intensive sectors in world (PérezLombard, Ortiz, González, \& Maestre, 2009). At the same time, it holds much promise: With current knowledge and technologies, these emissions could be reduced by $50 \%$ (from emissions in 2000) and in a cost-effective way (Newman, Beatley, \& Boyer, 2009). The building sector seems to offer the most low-cost potential to reduce carbon emissions in all world regions by the end of the next decade and is even expected to do so at a net cost benefit (IPCC, 2007).

Unfortunately, a series of regulatory failures and market shortfalls stand in the way of governments and market-players that wish to individually exploit the potential the building sector offers. It is therefore not surprising that much NEG activity is going on in this sector. But what are the outcomes of these NEG arrangements in the building sector? This is the central question that drives this research article. Based on a study of $20 \mathrm{NEG}$ arrangements in the Australian and Dutch building sectors, it aims to understand whether NEG has kept its (normative) promises. In doing so, it seeks to add to the growing empirical knowledge base of NEG. Section 2 discusses the various regulatory failures and market shortfalls that stand in the way of using the potential of the building sector to reduce carbon emissions. Section 3 then briefly addresses the current theory about NEG. Section 4 introduces research into the 20 NEG arrangements, building on interviews with 80 experts involved in these arrangements. Finally, in Section 5, the research findings are presented and Section 6 concludes with the main lessons learnt.

\section{Regulatory failures and market shortfalls}

The building sector faces a number of barriers that stand in the way of using the potential it holds to reduce carbon emissions. Most significant are regulatory failures that relate to the low replacement rates of buildings; and, relatedly, existing property rights. In developed economies buildings are constructed with a technical life expectancy of about fifty to a hundred years (Fay, Treloar, \& Iyer-Raniga, 2000). Yearly, approximately $2 \%$ of new buildings are added to the existing building stock, which makes for a replacement time of 40 to70 years (IEA, 2009). Normally, during their lifetime, buildings remain subject to the regulatory requirements that were in force when they were first occupied. Existing buildings are generally exempted from new or amended building regulations, a process more broadly referred to as 'grandfathering' (Vinagre Diaz, Wilby, \& Belén Rodríguez González, 2013). 
Thus, it may take a very long time until a regulatory requirement implemented today applies to the full (future) building stock - yet, by then, new insights will most likely require different regulatory requirements (cf., Newman, et al., 2009).

When seeking to introduce regulations for future buildings, governments face 'classical' regulatory complexities (for an extensive discussion of public building regulation, see Van der Heijden \& De Jong, 2009). For instance, the development of building regulation is a complicated process due to the important interests that are at stake for various parties. Original ambitious regulations may be watered down by the time of implementation as a result of mediating between these various interests (Jordan, 1999). Also, governments are often unable to keep up with the speed of technological development, which is especially relevant in terms of environmental sustainability (Balaras et al., 2007). Finally, the one-sizefits-all structure of traditional building regulations may go against the idea that attention to local circumstances is important for achieving a sustainable built environment (Yudelson, 2009).

Not only regulatory failures stand in the way of using the potential the building sector holds to reduce carbon emissions. Shortfalls in the (free) market, such as split incentives, conflicting interests, and the passing on of responsibilities add to these failures. Split incentives are situations where the party paying for the application of a solution does not receive the benefits. A typical example is a split incentive between a landlord and a tenant. Normally the landlord buys the energy-using equipment and ensures the energy efficiency of a building (i.e., the landlord owns the building envelope), and the tenant pays the energy bills. This gives the landlord little incentive to make changes to improve the energy-efficiency of the building or the equipment therein. Similarly, buildings are normally owned by a sequence of owners. Yet, the pay-back time of a solution intended to improve the sustainability of a building is often longer than the period an owner owns a building — this holds especially for houses. As such the current building owner often has no incentive to make the investment because it will be the future owner who gains most from it (Gillingham, Newell, \& Palmer, 2009).

A further complication is that the building sector is highly fragmented and characterised by a wide range of trades, such as architects, engineers, technical advisors, contractors, developers, investors, and property owners. These often have their own representative bodies, which lobby actively to see their interests served (Lillie \& Greer, 2007). The industry is characterised by a relatively small number of large players (i.e., international developers, architectural firms with offices around the globe, dominant 
construction material producers), and an uncountable number of small players (i.e., locally operating contractors, one-man architectural firms, highly specialised building construction producers). The interests of the various actors often conflict. A typical example is the development of the currently popular best-of-class building benchmarking arrangements (see Section 5). By requiring certain construction materials or certain construction processes, such arrangements limit market access for some players in the sector, whilst giving others a competitive advantage (Beddoes \& Booth, 2012).

Finally, the building sector is often considered to be a highly conservative sector, especially in terms of how it addresses environmental sustainability (Rees, 2009). In short, although technological solutions are available to reduce the impact the sector has on the natural environment, actors in the sector are not particularly willing to replace business-asusual technology with this new technology. One particular issue that stands out is the passing on of responsibilities by various actors in the sector, sometimes referred to as the "vicious circle of blame' (Cadman, 2007). This vicious circle of blame refers to a situation in which all parties involved blame each other for not providing, demanding or financing buildings with high levels of environmental performance. This suggests, so the argument goes, that occupants do not demand sustainable buildings because such buildings are not offered to them. Builders, in their turn, do not construct sustainable buildings because developers do not commission them. Developers, then, do not commission such buildings because investors do not fund them. Finally, investors do not fund sustainable buildings because they hold the opinion that there is no demand for these buildings - which brings us back to the occupants. This circle of blame has become a strong image in the building sector, with various organisations aiming to break it. For instance, the UK based Royal Institute of Chartered Surveyors (RICS) aims to change this vicious circle of blame into "virtuous loops of feedback and adaptation' (RISC, 2008).

Both the regulatory failures and the shortfalls of the (free) market are illustrations of the difficulties environmental governance has also been unable to overcome in other sociotechnical sectors such as agriculture, transport and energy (Ten Heuvelhof, de Jong, Kars, \& Stout, 2009). The current trend for NEG is expected to provide an answer to these issues. It should be noted that NEG arrangements are but one of many responses to the regulatory failures and market shortfalls discussed in Section 2. For instance, seeking to overcome these failures and shortfalls (city) governments are actively collaborating in government-togovernment networks such as ICLEI (Local Governments for Sustainability) and the C4O Cities Climate Leadership Group (see further, Hoffmann, 2011). It is however not the aim of 
this article to contrast the performance of NEG arrangements with the performance of other responses to the failures and shortfalls identified.

\section{$3 \quad$ NEG: a brief review of the literature and examples}

NEG fits into the discussions that started in the 1990s that build on the idea of a shift from government to governance (Rhodes, 1997). NEG is, however, not an approach to governance that is easy to capture and it is defined differently in the current literature (e.g., Backstrand, et al., 2010; Hoffmann, 2011; Holley, et al., 2012; Wurzel, et al., 2013). Yet some key characteristics recur. First, where traditional governance arrangements are often developed and implemented by either governmental or non-governmental actors, NEG builds on collaboration between the two (Holley, et al., 2012). This characteristic is, however, not truly "new". Collaboration between governmental and non-governmental actors is also key in the somewhat older network governance literature (Kickert, Klijn, \& Koppenjan, 1997) and the more recent collaborative governance literature (Ansell \& Gash, 2008). Second, where traditional governance arrangements are often based on direct regulation, financial incentives or communication, NEG often integrates these forms into innovative arrangements that are expected to achieve far more than the sum of their parts (Hoffmann, 2011). Again, it is questionable whether these characteristics are truly "new" to governance theorising. Scholars such as Neil Gunningham and Peter Grabosky already have argued for policy arrangements that build on a mix of incentives in their famous Smart Regulation (Gunningham \& Grabosky, 1998). Third, NEG theorising takes into account that context matters and that local problems can best be addressed on a local level (Gunningham, 2009). Again, this idea of localism may be traced back to the earlier governance literature (Jordan, et al., 2005). Finally, due to its collaborative nature, participation in NEG arrangements is often voluntary, as compared to mandatory participation in more traditional governance arrangements. Again, one may question whether this truly is a "new" addition to the governance literature. After all, voluntarism in (environmental) governance has been the topic of a wide range of publications (Potoski \& Prakash, 2009).

In combining these characteristics, NEG may, indeed, be considered a specific strand in the governance literature that seeks to understand the performance of governance arrangements that (i) have been developed in collaborations between governmental and nongovernmental actors, (ii) build on mixed incentives for participation, (iii) in which participation is voluntary, and (iv) that seek to address (local) problems with local solutions. 


\subsection{Examples of NEG in the building sector}

Two examples of NEG arrangements discussed in the current article may give some clarification of what real-world NEG arrangements look like in the building sector.

The Better Building Partnership, is a collaboration of Sydney's major property owners and the Sydney City Council which aims to improve the environmental performance of the city's commercial property (which currently accounts for about $50 \%$ of the city's carbon emissions). Through the Better Building Partnership, the Council learns how it can support property owners in terms of reducing legal barriers to, and the financial risks of, environmental upgrades to commercial property. The Council gains, as property owners make public commitments to reduce carbon emissions significantly beyond Australian legislature. The property owners learn from each other about how to cost-effectively reduce carbon emissions, and gain by seeing existing legal barriers removed and financial risks reduced. Participants praise the arrangement in terms of: (i) the relatively short two-year period of development, as contrasted with the lengthy process of having Australian building regulations changed; and, (ii) peer-pressure between the property owners (a) to participate, (b) to make far-reaching commitments in terms of reducing carbon emissions, and (c) to comply with these. Such peer-pressure is expected to add to the effectiveness of the Partnership, as well as to its accountability.

Another example is the Energy Leap in the Netherlands ('Energie Sprong'). Energy Leap aims to stimulate a transition to energy neutral buildings. It was developed by the Dutch Government in collaboration with a number of non-profit organisations. Its administration is commissioned by the Dutch Government to Platform31, a non-governmental organisation that seeks to develop knowledge on urban and regional development, and create networks between government, businesses and civil society. Under Energy Leap individuals and organizations, both public and private sector organisations, can submit their building projects for support to Platform31. Development or retrofitting projects to be supported are selected based on a number of specified criteria, mostly related to their level of ambition and innovativeness. Support comes in the form of hands-on information as well as financial support from the Dutch Government. By bringing together and supporting the leaders in the market Energy Leap aims to achieve concrete results, draw lessons, and disseminate knowledge about good practices. A highly accessible website is maintained (www.energiesprong.nl) that presents best-practices, a series of research reports, and information on how to apply for (financial) support. The arrangement is praised by its administrators and participants in terms of: (i) the position of Platform31 as an independent organisation between government, market and civil 
society; and, (ii) the flexibility in the arrangement to reward, target and stimulate leadership in the industry. Particularly the role of the independent Platform 31 is considered to strengthen the accountability of the arrangement.

\section{Towards a better understanding of NEG: NEG arrangements in Australia and the Netherlands}

Australia and the Netherlands provide intriguing contexts for a study of NEG. First of all, these countries have adopted NEG, which provides a pool from which cases can be selected. Secondly, the countries provide for a number of differences in the contexts of these NEG arrangements that may help to better understand their outcomes: (i) where the Netherlands is traditionally considered a leader in terms of environmental governance and having a culture of citizen awareness in terms of sustainability, Australia is a less positive example in such terms (Esty \& Porter, 2005; Jordan, et al., 2005); and, (ii) where the Netherlands has been severely affected by the global financial crisis of 2008 (and the Euro-crisis that followed), Australia has done remarkably well in terms of economic development (http://econ.worldbank.org/). This may shed some light on how these important contextual characteristics affect the development and performance of NEG arrangements.

\subsection{Research design}

In Australia and the Netherlands a wide range of NEG arrangements have emerged against the (legal) backdrop of building regulations that lack ambition in terms of environmental sustainability (cf., Thomas, 2010; Van Bueren \& Priemus, 2002). These arrangements address the carbon intensity of new or existing buildings, but all have a different approach to doing so. To give a broad brush overview before zooming in on the details in Section 5, the disparate NEG arrangements address different aspects of the larger, complex policy problems that the building sector poses. They have unpacked these complex problems into smaller and more manageable problems, and specific problem owners have come together to solve these. Among these, the problems of regulatory failure, split-incentives, conflicting interests, and the vicious circle of blame are addressed in a variety of ways, which will be discussed and evaluated.

To gain insight into whether and how NEG lives up to its assumed promises this article studies 20 NEG arrangements (14 in Australia, 6 in the Netherlands) such as the Better Buildings Partnership and Energy Leap. This stratified sample canvasses the type and content of a larger population of NEG arrangements that have been introduced globally 
(Backstrand, et al., 2010; Hoffmann, 2011; Holley, et al., 2012). The 20 cases were selected based on an extensive internet search using key words such as "sustainable development AND Australia", "sustainable building AND Australia", "green building AND Australia", "sustainable construction AND Australia", and "green construction AND Australia".

In order to understand the development process of these NEG arrangements, their particular form, and implementation a series of in-depth face-to-face interviews was carried out. Interviewees were targeted using snowball sampling and were selected for their expert knowledge of, and experience with, one or more of the NEG arrangements studied. This sampling resulted in a pool of 80 interviewees from various backgrounds - i.e. policy makers, administrators, investors, developers, architects, engineers, and property owners. Table 1 provides an overview of the interviewees.

\section{TABLE 1 ABOUT HERE.}

Interviews were based on a semi-structured questionnaire which provided a framework of checks and balances to assess the validity of findings (cf. Silverman, 2001). They were recorded and transcribed into a report that was sent back to interviewees for validation. Note that interviewees were often aware of, and involved in, more than one NEG arrangement. This allowed me discuss each arrangement, on average, with five participants. The data were processed by means of a systematic coding scheme, and qualitative data analysis software (Atlas.ti). The coding was carried out in three rounds, from 'roughly' coding parts of interviews where interviewees discussed for instance the outcomes of an arrangement, to 'fine-grained' coding within earlier identified codes when interviewees for instance discussed whether an arrangement was considered effective because it had resulted reduced carbon emissions (Appendix A provides an overview of the systematic coding scheme). Using this approach, the data was systematically explored, and insight was gained into the 'repetitiveness' and 'rarity' of experiences shared by the interviewees. Finally, to cross-check the validity of the data and findings, a document study of existing information on these NEG arrangements and existing research on NEG was carried out.

\section{$5 \quad$ Research findings}

Table 2 links the 20 NEG arrangements studied to the main problem they aim to overcome. It further links the specific NEG arrangements to those most affected by the problem, referred to as problem owners; and the approach chosen for addressing these problems. The 
arrangements will be discussed below, structured according to the specific problem they seek to address.

\section{TABLE 2 ABOUT HERE}

\subsection{Split incentives between property owners and tenants}

Tenants often have limited incentives to make improvements to the buildings they use since the pay-back time of an improvement is normally longer than their lease, and landlords not often allow their tenants to make changes to their buildings (Golove \& Eto, 1996). CitySwitch Green Office addresses these issues. This NEG arrangement aims to make Australian office tenants aware of the energy they use and how they can reduce this. It is administrated by local councils and state governments and serves as a platform for office tenants to learn about energy efficiency, share information, network, and showcase good practices. The arrangement aims to show tenants that there are limits to what they can do by changing work processes or making changes to a building's interior; and, that more may be expected if their

landlord makes (significant) changes to the building as a whole. As well as informing tenants, this arrangement helps tenants to put pressure on their landlords to improve the environmental performance of their buildings. Individual tenants often have limited power in a tenant-landlord relationship; a collective of tenants has more power, and even more so when supported by a government agency.

By participating in the arrangement, office tenants come to agreements with councils about their future environmental performance, and the council then provides support to help them meet these goals. In short, tenants agree to meet a particular rating within the voluntary National Australian Built Environment Rating System (NABERS), which seeks to the reduce energy and water consumption of existing buildings (NSW Government, 2011). Through linking the arrangement with this measurable goal, the risk of symbolic participation, or green wash (Lyon \& Maxwell, 2006), is partly overcome. Certain councils provide financial support, others facilitate meetings and ensure an ongoing supply and distribution of information. In return for signing an agreement with a local council on future targets to be met, participants may use the promotional CitySwitch Green Office logo; and, awards have been introduced to recognise leading practice. The ability to showcase leadership is considered a strong driver for participation, as a CitySwitch administrator explains: 
It is about leadership, it is about being seen to participate. ... The [NEG arrangement] helps leaders to feel good about what it is they are doing, and to have a place to speak about it (\#41). ${ }^{1}$

The arrangement's 2012 progress report claims that, compared to non-participants, CitySwitch participants 'boast an above NABERS rating' (CitySwitch, 2013, 14). This would indicate that participants on average use less energy and water in their buildings than non-participants. It remains unclear, however, whether CitySwitch attracts highly ambitious participants in the first place (i.e., those who already have high ranking NABERS ratings), or whether they become ambitious through participating.

\subsection{Split incentives between current and future property owners}

Similarly, current property owners often lack an incentive to improve their property, as the pay-back time of an energy conserving improvement is often longer than the time they will own their properties - which holds all the more true for home owners (Golove \& Eto, 1996). A traditional approach to overcoming this particular problem involves providing subsidies to property owners as an incentive to take away some of the financial barriers they experience. Such subsidies, however, have over the years faced severe criticism (Baldwin, Cave, \& Lodge, 2011). The most relevant criticism here is (i) that such subsidies only give an advantage to those who are able to obtain and understand the information related to the subsidies, and (ii) that it is difficult to monitor and enforce the standards of such subsidies during implementation. Various stories about "rooftop cowboys in the solar industry", where fraudulent contractors mislead homeowners about the costs of the instalment of solar panels (Peacock, 2013), underline this criticism.

Aiming to overcome these shortfalls in traditional subsidies, the Australian and Dutch governments seek to provide financial incentives but do so in the form of performance based grants, combined with information campaigns. Those seeking a grant must meet a certain

\footnotetext{
${ }^{1}$ In line with the custom of qualitative social science research, interviewees provided me with their insights in confidence. As such I cannot provide the identities of my interviewees unless they have given me explicit approval for doing so. To give the reader insight to the variety of interviews I quote in this research essay I refer to them with a number (e.g. ' $\# 50$ '). Please note that this research essay reports on a study that sits within a larger study, which addresses more than the 20 NEG-arrangements discussed here, and based on more than the 80 interviews used for the current research article. As such some interviewees are referred to with numbers higher than 80 .
} 
performance level, often within a specified time frame, and will face disciplinary measures if the performance is not met - e.g., the grant needs to be paid back to the grant providing organisation. Through intensive information campaigns the grant suppliers aim to reach and inform a large group of potential grantees about the possibilities and opportunities of the grants they supply - e.g., all 1.65 million households in the Australian state of Queensland under Climate Smart Living, and all 400+ housing corporations in the Dutch social rental sector under Sunny Rentals.

Interviewees were however critical about these NEG arrangements. They questioned whether the information supplied to such large numbers of individuals, often through brochures or information websites, would persist over time (cf., Schultz, Nolan, Cialdini, Goldstein, \& Griskevicius, 2007). This holds especially true for Climate Smart Living, which was concluded by the end of 2012 and thus lacks repeat encounters with participating households. With such large numbers of participants it also seems difficult to overcome the problem mentioned earlier, of monitoring and enforcement. The Climate Smart Living arrangement is criticized for a lack of efficiency exactly because it opened up opportunities for fraudulent practice, such as phony energy audits (Hurst, 2012). The sheer number of participants targeted also makes collaboration a complicated process. As an administrator from Sunny Rentals made clear: 'It is difficult to implement something on a large scale and get everyone on board. There are so many different organisational foci, so many decision making processes, so many people involved' (\#93). In this arrangement the time intensive process of collaboration was eventually sacrificed for a less time intensive form of top-down steering. That change appears to have caused a number of initial collaborators to step away from the arrangement in its current form.

\subsection{Conflicting interests between government and property owners}

In achieving high overall energy conservation in the building sector, it is important to move beyond the level of individual buildings. The interaction of infrastructure such as electricity supply, waste collection, and transport of people and goods to and from buildings has an especially significant impact on the energy performance of the building sector as a whole. In making investments in future infrastructure, cities may wish to know whether property owners and developers are willing to move to higher performing buildings; and if so, what is needed for them to do so. Property owners may wish to be informed about the direction a city may take in its infrastructure investments and legislative framework before making investments to improve their buildings' environmental performance. However, due to 
commercial pressures it is often not in the interest of individual property owners or developers to (publicly) share information about their ambitions and wishes.

This is what the Better Buildings Partnership, introduced above, aims to overcome. The Partnership was started in 2011, following examples in London and Toronto. The arrangement recognises that although commercial property owners have the ability to make major improvements to their individual buildings, they and the City of Sydney can achieve greater results if they collaborate. A Memorandum of Understanding was signed by the various parties stating that the property owners commit to the City's vision (the Sydney 2030 city plan) and that the City will support them in doing so. Although the City's administrators of the Partnership were very enthusiastic about the opportunities it could provide, participants were less positive about the actual results achieved through the Partnership. Apart from signing the Memorandums of Understanding, participants do not yet appear to have taken much additional action. Being involved in the policy making process, public recognition, and peer-pressure for now appear to be strong drivers for property owners to join and participate. As a representative of one of the participating landlords highlighted:

The value for us is in being at the table with our competitors and peers. I'm not sure what other value actually comes from the initiative than just being a part of what everybody is a part of at the moment (\#44).

Another approach to overcoming conflicting interests between governments and property owners comes in the form of covenants. Although this type of NEG arrangement has achieved considerable uptake as a way to steer the environmental behaviour of businesses in the Netherlands (Zito, Bruckner, Jordan, \& Wurzel, 2003) it was considered a rather novel approach in Australia. Through covenants, governments enter into agreements with an individual businesses or a particular area of the building sector (i.e., cement makers, timber producers) to find approaches by which the latter can improve their environmental performance. In the state of South Australia the government has signed Climate Sector Agreements with, among others, the cement sector, as well as with individual businesses such as major mining companies; and, under the Green Deals arrangement, the Dutch national government has entered into covenants with a range of individual businesses and local governments. A South Australian covenant between the government and mining company, for example, seeks to measure and report greenhouse gas emissions from the mining 
company and explores a global agreement for the steel industry. At the same time it provides the company with (inter)national recognition as being a leader in the industry.

Interestingly, different experiences were reported in the two countries. Interviewees in Australia were generally positive about the opportunities offered by covenants to both government and industry. Although interviewees mentioned the danger of capture related to such covenants (i.e. situations where the governed industry or business aims to see its private interest served over the public interest), they claimed that parties to the covenant feel pressure to comply with agreements made because covenants are often a public commitment between a government and a private party, which receives public attention through the (local) Australian media, and is normally publicly accessible on the internet. Only a small number of covenants have yet been signed.

The narrative about covenants in the Netherlands, as shared by Dutch interviewees, was less positive. Participation in the Green Deals was considered substantial, with over 200 proposals for covenants; yet, interviewees criticised the Green Deals for lacking ambition and a long-term structural approach to solving pressing environmental damage (\#76). Covenants were understood to provide individual businesses and particular parts of the building sector the opportunity to circumvent the introduction of environmental regulation. By showcasing a willingness to come to a solution to address environmental damage, and through collaborative processes with governments, participants may keep government attention away from implementing regulatory requirements (cf., Reid \& Toffel, 2009). Interviewees also reported difficulty for governments in enforcing covenants when the private party involved does not live up to its promises. Often the most 'serious' disciplinary measure for the government is to terminate the covenant, but that still leaves the government with unaddressed environmental risks, and often much time lost in developing and implementing the covenant. In short, after over 20 years of experience with covenants in the Netherlands, it may very well be that the private parties entering into these covenants have learned how to manipulate the system and exploit the weaknesses of covenants (cf., De Bruijn, Ten Heuvelhof, \& In 't Veld, 2010).

\subsection{Conflicting interests between leaders and laggards in the industry}

It is often difficult to distinguish the high performing buildings of leaders in the building sector, from those of laggards in the industry. Building codes are often considered the lowest common denominator that buildings have to meet, and, as with many regulated sectors, 
strong lobby groups aim to keep the regulatory requirements at low levels (Baldwin, et al., 2011). This is in the interest of laggards in the industry, but not in the interest of the leaders. In both Australia and the Netherlands leaders in the industry have set up a series of best-ofclass benchmarking arrangements which allow buildings or building products to be compared against each other based on their environmental performance - i.e., Green Star and EnviroDevelopment in Australia, and BREEAM-NL in the Netherlands. These arrangements rate the environmental performance of buildings or products on a scale - e.g., a number of stars indicates a certain performance. The criteria against which buildings or products are assessed are set by the arrangement's administrator, and assessment is generally carried out by a third party certifier. These arrangements generally leave it to the building owner or designer to choose a mixture of criteria to meet and reach a certain level of certification. Normally these arrangements set higher regulatory criteria than that required by a country's building regulatory framework, and participation in these arrangements is voluntary.

The major advantages of best of class benchmarking have been discussed elsewhere (e.g., Cooper \& Symes, 2009) and are confirmed by interviewees in the current research: (i) it is left to participants what level of environmental performance is sought; (ii) it is left to participants how this performance is reached; (iii) by benchmarking buildings or products against each other consumers have easy access to information about the building or product's environmental performance; and, (iv) for developers benchmarking is an attractive way of marketing a building's environmental credentials, which may make them willing to participate. Similarly, the downsides of benchmarking have been widely discussed, and were also confirmed by interviewees in the current research: (i) there is a tendency of developers to achieve the highest certification against the lowest costs, for instance by installing features that get high scores in the certification process but do not necessarily fit a more holistic idea of environmental performance; (ii) many of the arrangements certify buildings based on their design, or construction, but not on their performance when in use.

That said, this specific type of arrangement is the only one of all the studied arrangements that can be considered to have achieved significant numbers in terms of lowcarbon intensive buildings built or retrofitted. This holds especially true for the higher end of the commercial sector, and particular the higher end of the office market, as it is here where developers were said to see a market advantage in developing buildings with high levels of environmental performance. The arrangements are generally not considered to have much impact at the lower end of the commercial sector, or the residential sector in general. A senior manager at a major international development corporation explained: 
In the top-end of the office market you have large tenants, major public companies or large private companies, who take multiple floors. They have made a public commitment to be a sustainable business. That's driving it in terms of the outcomes of [benchmarking]. But in residential, the mums and dads, you don't have groups of people who come in and say: 'We all want to buy this.' At best you get one person out of twenty having a desire to live in a building that is green. The proportion isn't there yet (\#45).

\subsection{Developers blaming financing barriers}

Property owners often cannot find the necessary financing to upgrade their buildings. Banks are risk averse in supplying mortgages as the cost of upgrades are not (yet) represented in an increase in the buildings market value - i.e. the cost of the upgrade will be paid back by lower amenity costs, and expected higher rent rates (Pivo, 2010).

Addressing this particular issue, the Cities of Melbourne and Sydney have introduced NEG arrangements based on tripartite financing. These NEG arrangements are referred to as 1200 buildings in Melbourne and Environmental Upgrade Agreements in Sydney. In both cities the particular arrangements are founded on their overall city planning strategy. These NEG arrangements bring together local councils, a national bank, a major fund manager, the Australian Carbon Trust, and property owners in the cities' central business districts. The NEG arrangements are a vehicle to allow the local councils to enter into agreements with building owners and finance providers as a way of funding works to improve the environmental performance of those buildings. Under these NEG arrangements, the finance provider lends funds to a local council, which then supplies these funds to a building owner for environmental upgrades to its buildings. These funds are repaid through a local council charge on the land - i.e. the local council charges a fee, which is used to pay the loan to the finance provider. The agreement states the future environmental performance that is to be achieved, and stipulates a time frame for achieving this result (NSW Government, 2010).

The arrangements address problems faced by property owners in finding finance for retrofitting their buildings, but also help governments to achieve results in meeting their high targets. As an administrator of 1200 buildings explained:

Voluntary [arrangements] need to come with a tangible benefit. If you step back a bit you find that governments need to find out what their value proposition is [i.e., what 
is the financial incentive the government has to offer to participants?]. Without the [tripartite financing] our value proposition was limited to promotion, networks and knowledge. The finance incentive has created a strong value proposition and something that many Melbourne building owners are interested in (\#26).

But, as with many of the examples discussed above, these arrangements have not yet achieved significant numbers in terms of participants or actual buildings retrofitted: less than 10 Environmental Upgrade Agreements have been signed in Sydney; and, less than 50 buildings currently participate in the 1200 buildings arrangements in Melbourne. ${ }^{2}$

Another particular financial barrier discussed by developers are first mover disadvantages. These relate to the financial, legislative and cultural risks organisations face when bringing a new product or service to the market (Dobrev \& Gotsopoulos, 2010). The new product or service may be considered too expensive by clients; may conflict with existing legislation; or may face resistance when it is considered 'ahead of its time', or 'too fast for the market' (Robinson \& Min, 2002). Addressing first-mover disadvantages through subsidies is a well-known approach in environmental governance (Stewart, 2006); for instance, the provision of subsidies to households and firms for the instalment of solar panels. Yet, as discussed above, questions have arisen as to how successful traditional subsidies are in improving environmental performance, and sometimes it is even argued that subsidies may be harmful in doing so (Pearce, Porter, Steenblik, Pieters, \& Potier, 2003). Aiming to addressing these problems a range of Australian governments and the City of Amsterdam in the Netherlands are experimenting with best-performance grants. Best-performance grants challenge recipients to come up with innovative solutions to achieve high environmental performance of their (future) buildings. Competition between the grant-applicants is expected to continuously improve the environmental performance of the solutions they present to win grants.

Typically these best-performance grants are initiated and administered by local governments. They are the result of a collaborative development process in which the governments work together with businesses and non-government organisations. A representative example is South Australia's Buildings Innovation Fund, where the state government collaborates with the Adelaide City Council, the Property Council (a building sector interest group) and the University of South Australia in developing grant criteria and

\footnotetext{
${ }^{2}$ Data from: administrators in Sydney, \#39; \#41; \#42; and, Melbourne \#26.
} 
assessing applications. The strength of these grants, so explained a grant administrator, is that the outcomes provide 'solid business cases that innovative solutions to reduce carbon emissions [in the building sector] can be cost-effective' (\#51). The weakness of the grants, however, relates to their often small budget. For instance, the total funds available for the City of Amsterdam under its competitive grant NEG arrangement are only 80 million Euro keeping in mind that development projects often run up to tens if not hundreds of millions of Euros this grant will only be able to achieve limited results.

\subsection{Developers blaming regulatory barriers}

As well as providing funds to limit or take away first-mover financial risks, governments may support first-movers by removing legislative barriers (Frynas, Mellhali, \& Pigman, 2006). The building sector is notorious for legislative barriers that stand in the way of improved environmental performance (Bond, 2011). For instance, with current technologies it is possible to reclaim and reuse wastewater; however, sewage and drinking-water regulations often prevent this technology being implemented (Power, 2010).

Through Green Door the Queensland Government aims to provide regulatory relief to applicants of development proposals that aim to be leaders in terms of environmental performance. The Queensland Government works collaboratively with the development industry, local governments and referral agencies to identify the most sustainable development proposals in Queensland, and helps these to overcome regulatory barriers. Normally these relate to developers seeking to use innovative materials that are not yet accepted under current regulations. Under this NEG arrangement, development proposals that are identified as 'the most sustainable in Queensland' are fast-tracked in order to ensure 'exemplary sustainable developments delivered sooner throughout Queensland' (Queensland Government, 2011, 4). Or, in the words of a representative of a property and development interest group:

It was an acknowledgement that if they [the government] want to reach a certain state of outcomes, they need to make it easier for the people to go through the system (\#31).

But again, in practice only a small number of developers were found to make use of Green Doors. This only stresses the conservative nature of the building sector, as discussed earlier. 


\subsection{In summary}

In summary, in addressing a range of complex policy problems in the building sector a wide range of NEG arrangements have been introduced in Australia and the Netherlands. What binds these arrangements together is that (i) participation in all these arrangements is nonmandatory; (ii) they aim to achieve energy conservation in the building sector by overcoming particular barriers; (iii) they all move beyond existing regulatory requirements related to energy conservation and carbon emission reductions in the Australian building sector; and, (iv) local governments often play key-roles in their development or implementation.

However, with the exception of best-of-class benchmarking none of the arrangements studied has thus far achieved substantial outcomes in terms of buildings constructed or retrofitted with high levels of environmental performance.

\section{Discussion and conclusion}

This article questioned whether and how NEG arrangements can adequately address complex regulatory barriers and market shortfalls. Before coming to a conclusion about these issues, some caution is needed. The research approach that is chosen inevitably results in limitations as to the reach of the conclusions drawn. The research is exploratory and descriptive in nature and is predominantly based on the experiences of informed and involved actors, and builds on cases from the building sector only. More research on NEG in other sectors will be needed to assess the reach of the conclusions drawn here. Therefore, the insights and conclusions that follow do not claim empirical generalisation, but may provide bounded insights into 'basic patterns, or tendencies, so that other studies are likely to find something similar but not identical' - i.e., moderatum generalisation (Payne \& Williams, 2005, 297).

\subsection{General critique of NEG: much potential, limited outcomes}

To what extent do the NEG arrangements studied hold the potential to overcome complex policy problems? Interviewees generally agreed that NEG has considerable potential to reduce carbon emissions in the building sector by addressing these policy problems, but they also pointed to the relatively poor performance of the various arrangements studied. Some typical insights are provided in table 3.

\section{TABLE 3 ABOUT HERE}


The wider problem of significant carbon emissions in the building sector can, as shown in this article, be unpacked into smaller problems. In assigning these unpacked, smaller problems to specific problem owners, tailored policies may be developed and implemented. As compared to traditional government-led governance (i.e., direct regulation), such tailored policies may find a greater capacity, between the abilities of both governmental and nongovernmental actors, to adequately address policy problems. In the NEG arrangements studied, leaders in the industry, large property owners, building tenants and governmental agencies worked together to find solutions to regulatory failure, split-incentive barriers, conflicting interests and the circle of blame that are attractive and workable for all the parties involved. The interviewees were, generally, positive about this potential of NEG arrangements.

However, and although information on the outcomes of the arrangements studied, in terms of reduced carbon emissions, is limited, a compilation of the available 'performance' data provides a somewhat worrisome picture of the arrangements' performance. Most of the arrangements studied attracted only a limited number of participants or have resulted in a limited number of buildings with high levels of environmental performance. Only best-ofclass benchmarking arrangements have resulted in the construction of substantial numbers of buildings with high levels of environmental performance. However, they have only done so at the top end of the office market in Australia and the Netherlands (see also below). This type of arrangement has thus far been unable to affect the bulk of the building sector.

The general lack of meaningful outcomes in NEG arrangements is in line with a lack of performance of such arrangements that has been identified in the larger 'new' and voluntary environmental governance literature (e.g., Borck \& Coglianese, 2009; Karkkainen, 2004; Potoski \& Prakash, 2009; Schout, Jordan, \& Twena, 2010). The presented study provides some insight how this general poor performance may be improved.

\subsection{How to improve NEG performance?}

Why have the NEG arrangements studied not delivered on their expected outcomes? In what follows, three main insights from the study are provided that suggest strategies to improve NEG performance in the building sector as well as in other sectors. For each insight, a number of exemplary quotes from the interviews are provided.

Combine voluntary NEG arrangements with mandatory requirements to ensure better (future) outcomes; and use NEG arrangements to test (future) mandatory requirements. 


\section{TABLE 4 ABOUT HERE}

Perhaps the most intriguing insight is that the interviewees questioned one of NEG's key characteristics: its generally voluntary nature. The majority of the interviewees $(60 \%)$ suggested that these voluntary NEG arrangements need to be reinforced by mandatory requirements in order to be able to achieve significant results on a large scale and in a timely manner; table 4 provides some typical insights. Interviewees considered that the set of NEG arrangements studied has provided insightful lessons on how governmental actors and nongovernmental actors can collaborate, as well as insights on what particular incentives work for the various parties in the building sector.

This latter insight is especially important for the performance of NEG more generally. NEG arrangements can be approached as a strategy to develop and test future regulation. The evidence base of NEG arrangements possibly allows for the improvement of current regulatory requirements and the development of (future) regulations that build on different incentives for different parties in the building sector - as compared to the oft one-size-fits-all approach of current building regulation (see further Section 2).

Use NEG arrangements as a tailored approach in addressing regulatory barriers and market shortfalls, not as a one-size-fits-all solution

\section{TABLE 5 ABOUT HERE}

By and large, the interviewees believed that the top end of the office market in the central business districts of the larger-sized Australian and Dutch cities is currently sufficiently involved in these arrangements; table 5 provides some typical insights. The NEG arrangements that were considered to perform best are best-of-class benchmarking tools such as Green Star, EnviroDevelopment and BREEAM-NL. For the top end of the office market, the significant financial gains that can be achieved through an arrangement may very well be the major driver for active participation and related positive NEG outcomes. Buildings that are certified under benchmarking arrangements can be marketed as better, in one way or the other, than comparable buildings with lower levels of certification or without certification. Interviewees predominantly referred to occupants and owners of (future) buildings with highlevels of certification as being interested in such marketing of their buildings from a 
corporate social responsibility point of view (cf., Kemper \& Martin, 2010). In addition, in the top end of the commercial market, leadership matters, as the interviewees explained. NEG arrangements can acknowledge such leadership; particularly, the attention (local) governments give to the leaders in their NEG arrangements may be an incentive for participation.

Yet at the lower end of the office market, in less profitable locations in the non-major cities and in the residential sector, NEG arrangements were found to be less successful. Here, the financial gains for participants appear to be much lower, possibly too low to provide an attractive incentive for participation. Also, the interviewees argued, in these parts of the building sector, NEG arrangements built on marketability may not be the most suitable strategy. After all, homeowners and small and medium-sized businesses may feel less pressure (if any pressure at all) from their peers, shareholders and clients to showcase their environmental credentials. Also, in this part of the building sector, leadership was considered less relevant by the interviewees for similar reasons.

This insight further stresses that the performance of NEG arrangements is limited by their designs and contexts. It also gives a more in-depth understanding of how the needs of (prospective) 'clients' of NEG arrangements need to be included in their designs. It is unlikely that one-size-fits-all arrangements will achieve high levels of effectiveness, and more is to be expected from arrangements that are tailored to the needs of their clients.

Governments need to become more active in NEG arrangements, and in particular, in ensuring coherence and building bridges between various arrangements.

\section{TABLE 6 ABOUT HERE}

The interviewees considered (local) governments to be pivotal for improving the performance of NEG arrangements; table 6 provides some typical insights. First, and following from the above findings, the interviewees considered that (local) governments need to back the NEG arrangements up with mandatory requirements to ensure an uptake of the arrangements on a much larger scale.

Second, the interviewees also considered that (local) governments need to become more active in attracting participants to NEG arrangements. They can do so by organising more meetings to inform potential participants about NEG arrangements or they can do so by providing clear(er) information about NEG arrangements on their websites. The latter may 
attract participants, particularly when it becomes clear what exactly is in it for them. CitySwitch Green Office is an illustrative example of an NEG arrangement that shares much information, lessons and best-practices openly with all interested parties.

Third, and perhaps most insightful, the individual NEG arrangements together make up a larger system of governance. Particularly, (local) governments can strongly influence this larger system of governance. They have the ability to bridge NEG arrangements in such a way that synergies between the arrangements are created. Of particular interest is the role the Sydney City Government plays in a number of NEG arrangements that were studied. It is, for instance, actively involved in the Better Building Partnership, Environmental Upgrade Agreements and CitySwitch Green Office. The first two arrangements address commercial property owners and the latter addresses commercial property tenants. The interviewees explained that, by bringing these various groups together in a single forum, they can, supported by the City of Sydney, discuss and address problems related to the environmental performance that these groups cannot solve individually. This is a clear example of how (local) governments may be facilitative in addressing the split-incentives discussed in Section 2 of this article. In creating such synergies, (local) governments may seek to ensure that the whole of NEG arrangements is larger than the sum of its parts.

The roles of government in NEG arrangements and their impact on the outcomes of these has been understudied in the current literature (cf., Bell \& Hindmoor, 2009). The involvement of government in particular roles, however, seems pivotal for NEG success (cf., Koch, 2013) and may require more attention in future studies on NEG.

\subsection{Conclusion}

The current study indicates that NEG is not a panacea for addressing regulatory barriers and market shortfalls. They are limited by their design and context in achieving successful outcomes, and overall NEG does not appear to result in sweeping outcomes. This is not a novel insight in itself (Borck \& Coglianese, 2009; Gunningham, 2009; Koehler, 2007). Yet, given all NEG activity in the building sector and in other sectors it may be of relevance to remind ourselves about the bounded effectiveness of NEG. The study has further pointed to a number of design and contextual characteristics that may help to improve (future) NEG arrangements.

What way forward then with NEG? Although the above findings seem to imply that more NEG arrangements are needed to achieve better results, there may be a saturation point for NEG arrangements. A set of NEG arrangements that is too large may result in 
'participation fatigue' when participants become involved in different arrangements that all require time and effort and all address slightly different aspects of the same thing. Interviewees were also concerned that too much NEG activity may result in a race of the arrangements to the bottom. In order to be successful, these arrangements need a certain number of participants (Potoski \& Prakash, 2009) and various arrangements may very well compete for participants. A danger thus exists that, under such competition, administrators of these arrangements may become more lenient or lower standards to make it easier for participants to become involved (ibid.).

Instead of introducing more and more new NEG arrangements, it may be better to begin singling out and scaling up those NEG arrangements that have proven to be successful in overcoming regulatory barriers and market shortfalls. Governments may play key roles in this. Through marketing and the sharing of lessons learnt from these successful arrangements, governments may seek to increase the number of participants involved in them and to improve their performance. They may also seek to integrate these NEG arrangements in their regulatory frameworks, or to simply mandate participation in NEG arrangements that have proven to be successful. Finally, governments may further catalyse the performance of these particular arrangements by seeking synergies among them. 


\section{Tables}

Table 1 - Interviewees’ background

\begin{tabular}{|c|c|c|}
\hline Interviewee background & Government & Non-government \\
\hline Policy maker & $\begin{array}{c}8 \text { (4 Australian/4 } \\
\text { Dutch) }\end{array}$ & \\
\hline Administrator & $\begin{array}{c}26 \text { (22 Australian } \\
\text { /4 Dutch) }\end{array}$ & $\begin{array}{c}15 \text { (12 Australian } \\
\text { /3 Dutch) }\end{array}$ \\
\hline Architect, engineer, advisor & & $\begin{array}{c}11 \text { (5 Australian } / 6 \\
\text { Dutch) }\end{array}$ \\
\hline Contractor, developer & & $\begin{array}{c}7 \text { (3 Australian } / 4 \\
\text { Dutch) }\end{array}$ \\
\hline Property owner & & $\begin{array}{c}7 \text { (4 Australian } / 3 \\
\text { Dutch) }\end{array}$ \\
\hline Other & & $\begin{array}{c}6 \text { (3 Australian } / 3 \\
\text { Dutch) }\end{array}$ \\
\hline Total & $\begin{array}{c}34 \text { (26 Australian } \\
\text { /8 Dutch) }\end{array}$ & $\begin{array}{c}46 \text { (27 Australian } \\
\text { /19 Dutch) }\end{array}$ \\
\hline
\end{tabular}

Table 2 - The specific problems addressed by the studied NEG arrangements, the problem owners involved, and their approaches to addressing the problems.

\begin{tabular}{|l|l|l|l|l|}
\hline $\begin{array}{l}\text { Specific } \\
\text { problem }\end{array}$ & $\begin{array}{l}\text { Problem } \\
\text { owners }\end{array}$ & $\begin{array}{l}\text { NEG } \\
\text { arrangement } \\
\text { (reach and year } \\
\text { of } \\
\text { implementation)* }\end{array}$ & Approach & $\begin{array}{l}\text { Role of government } \\
\text { in arrangement }\end{array}$ \\
\hline $\begin{array}{l}\text { Split- } \\
\text { incentives } \\
\text { between } \\
\text { property } \\
\text { owners and } \\
\text { tenants }\end{array}$ & $\begin{array}{l}\text { Texisting } \\
\text { commercial } \\
\text { buildings }\end{array}$ & $\begin{array}{l}\text { CitySwitch Green } \\
\text { Office (Australia- } \\
\text { wide; 2010) }\end{array}$ & $\begin{array}{l}\text { Information } \\
\text { networks } \\
\text { combined with } \\
\text { empowerment }\end{array}$ & $\begin{array}{l}\text { CitySwitch: initiator } \\
\text { and administrator of } \\
\text { arrangement, financial } \\
\text { support for } \\
\text { participants. }\end{array}$ \\
\hline $\begin{array}{l}\text { Split- } \\
\text { incentives }\end{array}$ & $\begin{array}{l}\text { Current } \\
\text { building }\end{array}$ & $\begin{array}{l}\text { Climate Smart } \\
\text { Living }\end{array}$ & $\begin{array}{l}\text { Performance } \\
\text { grants }\end{array}$ & $\begin{array}{l}\text { Climate Smart Living: } \\
\text { initiator and }\end{array}$ \\
\hline
\end{tabular}




\begin{tabular}{|c|c|c|c|c|}
\hline $\begin{array}{l}\text { between } \\
\text { current and } \\
\text { future } \\
\text { property } \\
\text { owners }\end{array}$ & owners & $\begin{array}{l}\text { (Queensland; } \\
\text { 2009); Sunny } \\
\text { Rentals } \\
\text { (Netherlands wide; } \\
\text { 2011); Energy } \\
\text { Leap (Netherlands } \\
\text { wide; 2011) }\end{array}$ & $\begin{array}{l}\text { combined with } \\
\text { information } \\
\text { supply }\end{array}$ & $\begin{array}{l}\text { administrator of } \\
\text { arrangement, financial } \\
\text { support for } \\
\text { participants. } \\
\text { Sunny Rentals: } \\
\text { financial support for } \\
\text { participants. } \\
\text { Energy Leap: initiator } \\
\text { and administrator of } \\
\text { arrangement, financial } \\
\text { support for } \\
\text { participants. }\end{array}$ \\
\hline \multirow[t]{2}{*}{$\begin{array}{l}\text { Conflicting } \\
\text { interests } \\
\text { between } \\
\text { government } \\
\text { and property } \\
\text { owners }\end{array}$} & \multirow[t]{2}{*}{ Government } & $\begin{array}{l}\text { Better Building } \\
\text { Partnership } \\
\text { (Sydney; 2011) }\end{array}$ & $\begin{array}{l}\text { Elite networks } \\
\text { combined with } \\
\text { regulatory } \\
\text { relief }\end{array}$ & $\begin{array}{l}\text { Better Building } \\
\text { Partnership: initiator } \\
\text { and administrator of } \\
\text { arrangement, financial } \\
\text { support for } \\
\text { participants. }\end{array}$ \\
\hline & & $\begin{array}{l}\text { Climate Sector } \\
\text { Agreements (South } \\
\text { Australia; 2009); } \\
\text { Green Deals } \\
\text { (Netherlands wide; } \\
\text { 2011); }\end{array}$ & Covenants & $\begin{array}{l}\text { Climate Sector } \\
\text { Agreements: initiator } \\
\text { and administrator of } \\
\text { arrangement. } \\
\text { Green Deals: initiator } \\
\text { and administrator of } \\
\text { arrangement, financial } \\
\text { support for } \\
\text { participants. }\end{array}$ \\
\hline \multirow[t]{2}{*}{$\begin{array}{l}\text { Conflicting } \\
\text { interest } \\
\text { between } \\
\text { leaders and } \\
\text { laggards }\end{array}$} & \multirow[t]{2}{*}{$\begin{array}{l}\text { Leaders in } \\
\text { the industry }\end{array}$} & $\begin{array}{l}\text { Green Star } \\
\text { (Australia wide; } \\
\text { 2003); } \\
\text { EviroDevelopment } \\
\text { (Australia wide; ); } \\
\text { Sustainable Port } \\
\text { Development } \\
\text { (Ports of Sydney; } \\
\text { 2006); BREEAM- } \\
\text { NL (Netherlands } \\
\text { wide; 2011) }\end{array}$ & $\begin{array}{l}\text { Best of class } \\
\text { benchmarking }\end{array}$ & $\begin{array}{l}\text { Green Star: joint- } \\
\text { initiator of } \\
\text { arrangement. } \\
\text { EnviroDevelopment: } \\
\text { joint-initiator of } \\
\text { arrangement; financial } \\
\text { support for } \\
\text { arrangement in first } \\
\text { years. } \\
\text { Sustainable Port } \\
\text { Development: indirect } \\
\text { support (financial). } \\
\text { BREEAM-NL: joint- } \\
\text { initiator of } \\
\text { arrangement. }\end{array}$ \\
\hline & & ESCos & Energy Service & ESCos: financial \\
\hline
\end{tabular}




\begin{tabular}{|c|c|c|c|c|}
\hline & & $\begin{array}{l}\text { (Netherlands wide; } \\
\text { 2010) }\end{array}$ & Companies & $\begin{array}{l}\text { support for } \\
\text { development of } \\
\text { contract. }\end{array}$ \\
\hline \multirow[t]{2}{*}{$\begin{array}{l}\text { Circle of } \\
\text { blame } \\
\text { (developers } \\
\text { blaming } \\
\text { financial } \\
\text { barriers) }\end{array}$} & $\begin{array}{l}\text { Owners of } \\
\text { existing } \\
\text { commercial } \\
\text { buildings }\end{array}$ & $\begin{array}{l}\text { 1200 Buildings } \\
\text { (Melbourne; } \\
\text { 2010); } \\
\text { Environmental } \\
\text { Upgrade } \\
\text { Agreements } \\
\text { (Sydney; 2011) }\end{array}$ & $\begin{array}{l}\text { Financial } \\
\text { intercession }\end{array}$ & $\begin{array}{l}1200 \text { Buildings: } \\
\text { initiator and } \\
\text { administrator of } \\
\text { arrangement. } \\
\text { Environmental } \\
\text { Upgrade Agreements: } \\
\text { initiator and } \\
\text { administrator of } \\
\text { arrangement. }\end{array}$ \\
\hline & $\begin{array}{l}\text { Developers, } \\
\text { builders and } \\
\text { owners of } \\
\text { new and } \\
\text { existing } \\
\text { commercial } \\
\text { buildings; } \\
\text { and new and } \\
\text { existing } \\
\text { residential } \\
\text { buildings }\end{array}$ & $\begin{array}{l}\text { Building } \\
\text { Innovation Fund } \\
\text { (South Australia; } \\
\text { 2011); Sustainable } \\
\text { Development } \\
\text { Grant (Brisbane; } \\
\text { 2009); Smart } \\
\text { Green Apartments } \\
\text { (Sydney; 2012); } \\
\text { Lord Mayor Grant } \\
\text { (Brisbane; 2011); } \\
\text { Zero Carbon } \\
\text { Challenge (South } \\
\text { Australia; 2011); } \\
\text { Sustainability } \\
\text { Fund (State of } \\
\text { Victoria; 2005); } \\
\text { Amsterdam } \\
\text { Investment Fund } \\
\text { (Amsterdam; } \\
\text { 2011) }\end{array}$ & $\begin{array}{l}\text { Best- } \\
\text { performance } \\
\text { grants }\end{array}$ & $\begin{array}{l}\text { Building Innovation } \\
\text { Fund: initiator and } \\
\text { administrator of } \\
\text { arrangement, financial } \\
\text { support for } \\
\text { participants. } \\
\text { Sustainable } \\
\text { Development Grant: } \\
\text { initiator and } \\
\text { administrator of } \\
\text { arrangement, financial } \\
\text { support for } \\
\text { participants. } \\
\text { Smart Green } \\
\text { Apartments: joint- } \\
\text { initiator and } \\
\text { administrator of } \\
\text { arrangement, financial } \\
\text { support for } \\
\text { participants. } \\
\text { Lord Mayor Grant: } \\
\text { initiator and } \\
\text { administrator of } \\
\text { arrangement, financial } \\
\text { support for } \\
\text { participants. } \\
\text { Zero Carbon } \\
\text { Challenge: initiator } \\
\text { and administrator of } \\
\text { arrangement, financial } \\
\text { support for }\end{array}$ \\
\hline
\end{tabular}




\begin{tabular}{|c|c|c|c|c|}
\hline & & & & $\begin{array}{l}\text { participants. } \\
\text { Sustainability Fund: } \\
\text { initiator and } \\
\text { administrator of } \\
\text { arrangement, financial } \\
\text { support for } \\
\text { participants. } \\
\text { Amsterdam Investment } \\
\text { Fund: initiator of } \\
\text { arrangement, financial } \\
\text { support for } \\
\text { participants. }\end{array}$ \\
\hline $\begin{array}{l}\text { Circle of } \\
\text { blame } \\
\text { (developers } \\
\text { blaming } \\
\text { regulatory } \\
\text { barriers) }\end{array}$ & $\begin{array}{l}\text { Developers } \\
\text { and future } \\
\text { owners of } \\
\text { new } \\
\text { commercial } \\
\text { and } \\
\text { residential } \\
\text { buildings }\end{array}$ & $\begin{array}{l}\text { Green Door } \\
\text { (Queensland; } \\
\text { 2011); Green } \\
\text { Strata (Australia } \\
\text { wide; 2011) }\end{array}$ & $\begin{array}{l}\text { Regulatory } \\
\text { relief }\end{array}$ & $\begin{array}{l}\text { Green Door: initiator } \\
\text { and administrator of } \\
\text { arrangement. } \\
\text { Green Strata: } \\
\text { financial support for } \\
\text { arrangement in first } \\
\text { years. }\end{array}$ \\
\hline
\end{tabular}

* An overview of all NEG arrangements studied is available from www.EnviroVoluntarism.info

Table 3 - Some typical insights

\begin{tabular}{|l|l|}
\hline Interviewee & Quote \\
\hline$\# 50$ & $\begin{array}{l}\text { The failing of [this NEG arrangement] has been that it promised big } \\
\text { reductions in carbon emissions, but up to now, this has not been realised [due } \\
\text { to a lack of participation]. With [mandatory] carbon pricing as an addition [it] } \\
\text { may be sped up. }\end{array}$ \\
\hline$\# 51$ & $\begin{array}{l}\text { What you often found was that these reports [on energy efficiency measures to } \\
\text { be taken (these reports are part of a NEG arrangement)] ended up on the shelf } \\
\text { and no follow-up action was taken. }\end{array}$ \\
\hline$\# 66$ & $\begin{array}{l}\text { There were issues with how the [NEG arrangement] was implemented. At } \\
\text { first, it was all pilots. But you have to scale it up [which was not done]. If you } \\
\text { don't, you won't generate the change we are all looking for }\end{array}$ \\
\hline$\# 75$ & $\begin{array}{l}\text { The biggest problem here in (...) is that we are absolutely not focused on } \\
\text { results and learning. We like to start new pilot studies and experiments [with } \\
\text { NEG arrangements], but we do not care about their results }\end{array}$ \\
\hline
\end{tabular}


Table 4 - Some typical insights

\begin{tabular}{|l|l|}
\hline Interviewee & Quote \\
\hline$\# 32$ & $\begin{array}{l}\text { It is not the norm [yet]. Most companies don't offset their emissions under a } \\
\text { voluntary [NEG arrangement]. Most organisations won't do it unless they are } \\
\text { mandated to do it. }\end{array}$ \\
\hline$\# 33$ & $\begin{array}{l}\text { The speed with which we react is out of sync with the problems we face. } \\
\text { Although a lot of voluntary [NEG arrangements] make sense, they are not fast } \\
\text { enough in addressing problems. Regulation is needed. }\end{array}$ \\
\hline$\# 41$ & $\begin{array}{l}\text { Mandatory is the way to go. And that probably is a funny answer from } \\
\text { somebody who runs a voluntary [NEG arrangement]. Well, there probably is } \\
\text { room for both, but if we make the changes in the timeline we need to make } \\
\text { them, then we've got to toughen up here. }\end{array}$ \\
\hline
\end{tabular}

Table 5 - Some typical insights

\begin{tabular}{|l|l|}
\hline Interviewee & Quote \\
\hline$\# 43$ & $\begin{array}{l}\text { The top end of any market does need to demonstrate leadership in certain } \\
\text { areas. That is why they are the top end. (...) One of these credentials [to } \\
\text { showcase leadership] is to be environmentally sensible and understand those } \\
\text { issues. So that's a criteria that more people and more people [seek to] meet [by } \\
\text { joining NEG arrangements]. }\end{array}$ \\
\hline$\# 30$ & $\begin{array}{l}\text { Why isn't everyone [participating in NEG arrangements]? For some large } \\
\text { corporations, it comes down to corporate sustainability reporting. For some of } \\
\text { our industrial members, it comes down to the fact that they want to attract } \\
\text { global companies that have performance requirements about being positioned } \\
\text { in an environmentally sustainable state, or something like that. (...) But [that] } \\
\text { obviously [is] only a certain part of the market. }\end{array}$ \\
\hline$\# 64$ & $\begin{array}{l}\text { It all boils down to [the question of] who wants a sustainable building? Project } \\
\text { developers and investors work from their current risk profiles. High-end } \\
\text { tenants ask for sustainable buildings. They need [a building acknowledged } \\
\text { under a NEG regime] to meet their CSR [corporate responsibility targets]. To } \\
\text { put it in their CSR reports. These people want to pay for it. The residential } \\
\text { sector is complicated. Homeowners and users don't ask for sustainability. }\end{array}$ \\
\hline
\end{tabular}

Table 6 - Some typical insights

\begin{tabular}{|l|l|}
\hline Interviewee & Quote \\
\hline$\# 78$ & $\begin{array}{l}\text { There's much uncertainty in the industry. There are so many certificates and } \\
\text { [other NEG arrangements] around. People have a hard time understanding } \\
\text { what is required in terms of sustainability. The government may take up a role } \\
\text { of streamlining all this. We don't need more fragmentation. }\end{array}$ \\
\hline$\# 24$ & $\begin{array}{l}\text { We [a government agency] make sure to get the minimum level [for } \\
\text { sustainable construction] set and have buildings achieve this. We don't have a } \\
\text { problem if you wish to go above and beyond this. It would be nice if there was }\end{array}$ \\
\hline
\end{tabular}




\begin{tabular}{|l|l|}
\hline \multirow{2}{*}{$\begin{array}{l}\text { Some harmonisation between the different [NEG arrangements]. [Arrangement } \\
\mathrm{X} \text { ] already builds on the [mandatory] codes. I think it is good to have that } \\
\text { consistency. }\end{array}$} \\
$\begin{array}{l}\text { As an organisation like ours [an agency at arm's length of government], you } \\
\text { are able to significantly influence the market. Even without financial } \\
\text { incentives, much can be achieved by connecting people and organisations and } \\
\text { by collecting and circulating insights [from NEG arrangements]. You know, } \\
\text { we are a recognised name. [The building sector considers] us an independent } \\
\text { and trustworthy source of information. }\end{array}$ \\
\hline
\end{tabular}




\section{Appendix A - codes used for data analysis}

The list below are the codes used for analyzing the data. The data was coded in three stages. First a rough coding was carried out (bold codes). Second an intermediate coding was carried out (underlined codes). And finally, a fine grained coding was carried out (codes in italics). Codes are derived from an extensive review of the literature (Anonymous, 2012).

\section{Development process}

Collaboration/participation

Consensus building

Deliberation/discussion/dialogue

Heterarchy

Devolved decision making

Context based

Ongoing learning and readjustment

\section{Arrangement structure}

Flexibility

Transparency

Soft law mechanisms

Target and result orientation

Clear rules

Adaptable rules

Enforcement and monitoring

Self-monitoring

Administered monitoring

Third party monitoring

Government monitoring

Sanctioning

Warning

Financial penalty

Reputational penalty (shaming)

$\underline{\text { Rewards }}$

Information

Interaction with government

Public recognition

Financial gain

\section{Outcome}

Effective

Improving environmental

performance

Reducing CO2 emissions

Not effective

Too slow for change

Mandatory is needed

$\underline{\text { Efficient }}$

Cost-effective

Not efficient

\section{Development motivations}

Affirmative

Showcasing good practice

Cheaper than formal regulation

Cost savings

Green consumers

Green financing

Negative

Prevent future regulation

Hindering competitors

Societal pressure

Worker pressure

$\underline{\text { Industry characteristics }}$

Innovative industry

Strong internal competition

Strong international focus

High organizational capability

\section{Participation motivations}

Affirmative

Altruism

Showcasing good practice

Cost savings (general)

Energy cost savings

Green consumers

Green financing

Regulatory relief

Negative

Peer-pressure

Societal-pressure

Reputational harm

Liability and legitimacy

Poor past performance 


\section{References}

Ansell, C., \& Gash, A. (2008). Collaborative Governance in Theory and Practice. Journal of Public Administration Research and Theory, 18(4), 543-571.

Backstrand, K., Khan, J., Kronsell, A., \& Lovbrand, E. (2010). Environmental politics and deliberative democracy. Cheltenham: Edward Elgar.

Balaras, C., Gaglia, A., Georgopoulou, E., Mirasgedis, S., Srafidis, Y., \& Lalas, D. (2007). European residential buildings and empirical assessment of the Hellenic building stock, energy consumption, emissions and potential energy savings. Building and Environment, 42(3), 1298-1314.

Baldwin, R., Cave, M., \& Lodge, M. (2011). Understanding Regulation. Oxford: Oxford University Press.

Beddoes, D., \& Booth, C. (2012). Insights and Perceptions of Sustainable Design and Construction. In C. Booth, F. Hammond, J. Lamond \& D. Proverbs (Eds.), Solutions for Climate Change Challenges in the Built Environment (pp. 127-140). Oxford: Wiley-Blackwell.

Bell, S., \& Hindmoor, A. (2009). Rethinking Governance. Cambridge: Cambridge University Press.

Bond, S. (2011). Barriers and drivers to green buildings in Australia and New Zealand. Journal of Property Investment \& Finance, 29(4/5), 494-509.

Borck, J., \& Coglianese, C. (2009). Voluntary Environmental Programs. Annual Review of Environmental Resources, 34, 305-324.

Cadman, D. (2007). The Vicious Circle of Blame. Bristol: University of the West of England.

Cashore, B., Auld, G., \& Newsom, D. (2004). Governing Through Markets. New Haven: Yale University Press.

CitySwitch. (2013). 2012 Progress Report. Sydney: CitySwitch.

Cooper, I., \& Symes, M. (2009). Sustainable Urban Development. Volume 4. London: Routledge.

De Bruijn, H., Ten Heuvelhof, E. F., \& In 't Veld, R. J. (2010). Process Management. Heidelberg: Springer.

De Búrca, G., \& Scott, J. (2006). New governance and constitutionalism in Europe and the US. Oxford: Hart.

Dobrev, S., \& Gotsopoulos, A. (2010). Legitimacy vacuum, structural imprinting, and the first mover disadvantage. Academy of Management Journal, 53(5), 1153-1174.

Esty, D., \& Porter, M. (2005). National environmental performance. Environment and Development Economics, 10(4), 391-434.

Fay, R., Treloar, G., \& Iyer-Raniga, U. (2000). Life-cycle energy analysis of buildings. Building Research \& Information, 28(1), 31-41.

Frynas, J. G., Mellhali, K., \& Pigman, G. A. (2006). First mover advantages in international business and firm-specific political resources. Strategic Management Journal, 27(4), 321-345.

Gillingham, K., Newell, R., \& Palmer, K. (2009). Energy Efficiency Economics and Policy. Cambridge, MA: National Bureau of Economics and Policy.

Golove, W., \& Eto, J. (1996). Market barriers to energy efficiency. Berkely: University of California.

Gunningham, N. (2009). The New Collaborative Governance. Journal of Law and Society, $36(1), 145-166$.

Gunningham, N., \& Grabosky, P. (1998). Smart Regulation. Oxford: Oxford University Press.

Hoffmann, M. (2011). Climate Governance at the Crossroads. Oxford: Oxford University Press. 
Holley, C., Gunningham, N., \& Shearing, C. (2012). The New Environmental Governance. London: Routledge.

Hurst, D. (2012, 26 April). Power-saving scheme axed, BrisbaneTimes.com. Retrieved from http://www.brisbanetimes.com.au/queensland/powersaving-scheme-axed-201204261xmyo.html

IEA. (2009). World Energy Outlook 2009. Paris: International Energy Agency/OECD.

IPCC. (2007). Contribution of Working Group III to the Fourth Assessment Report of the Intergovernmental Panel on Climate Change. Cambridge: Cambridge University Press.

Jordan, A. (1999). The implementation of EU environmental policy. Environment and Planning C, 17(1), 69-90.

Jordan, A., Wurzel, R., \& Zito, A. (2005). The Rise of New Policy Instruments in Comparative Perspective. Political Studies, 53(3), 477-496.

Karkkainen, B. (2004). "New Governance" in Legal Thought and the World. Minnesota Law Review, 89(471-497), 77-99.

Kemper, A., \& Martin, R. L. (2010). After the fall. European Management Review, 7(4), 229239.

Kickert, W., Klijn, E.-H., \& Koppenjan, J. (1997). Managing Complex Networks. London: Sage.

Koch, P. (2013). Overestimating the Shift from Government to Governance. Governance, 26(3), 397-423.

Koehler, D. A. (2007). The Effectiveness of Voluntary Environmental Programs. The Policy Studies Journal, 35(4), 689-722.

Lillie, N., \& Greer, I. (2007). Industrial relations, migration and neo-liberal politics. Politics and Society, 35(4), 551-581.

Lubell, M. (2004). Collaborative environmental institutions. Journal of Policy Analysis and Management, 23(3), 549-573.

Lyon, T. P., \& Maxwell, J. W. (2006). Greenwash. Ann Arbor: Ross School of Business.

Newman, P., Beatley, T., \& Boyer, H. (2009). Resilient Cities. Washington: Island Press.

NSW Government. (2010). Local Government Amendment Act 2010 No 110. Sydney: Government of New South Wales.

NSW Government. (2011). National Australian Built Environment Rating System. Sydney: New South Wales Government.

Payne, G., \& Williams, M. (2005). Generalization in Qualitative Research. Sociology, 39(2), 295-314.

Peacock, F. (2013). Solar Cowboys Retrieved 11 April 2013, from www.solarquaotes.com.au/blog/category/solar-cowboys/

Pearce, D., Porter, G., Steenblik, R., Pieters, J., \& Potier, M. (2003). Envrionmentally harmful subsidies. Paris: OECD.

Pérez-Lombard, L., Ortiz, J., González, R., \& Maestre, I. R. (2009). A review of benchmarking, rating and labelling concepts within the framework of building energy certification schemes. Energy and Buildings, 41(3), 272.

Pivo, G. (2010). Owner-Tenant Engagement in Sustainable Property Investing. The Journal of Sustainable Real Estate, 2(1), 183-199.

Potoski, M., \& Prakash, A. (2009). Voluntary Programs. Cambridge: MIT Press.

Power, K. (2010). Recycled water use in Australia. Canberra: National Water Commission.

Queensland Government. (2011). Green Door information paper. Brisbane: Queensland Government.

Rees, W. (2009). The ecological crisis and self-delusion. Building Research \& Information, $37(3), 300-311$. 
Reid, E. M., \& Toffel, M. W. (2009). Responding to public and private politics. Strategic Management Journal, 30(11), 1157-1178.

Rhodes, R. A. W. (1997). Understanding governance. Buckingham; Philadelphia: Open University Press.

RISC. (2008). Breaking the Vicious Circle of Blame. London: Royal Institute of Chartered Surveyors.

Robinson, W., \& Min, S. (2002). Is the first to market the first to fail. Journal of Marketing Research, 39(1), 120-128.

Sabel, C., \& Zeitlin, J. (2012). Experimentalism in the EU. Regulation \& Governance, 6(3), 410-426.

Schout, A., Jordan, A., \& Twena, M. (2010). From 'Old' to 'New' Governance in the EU. West European Politics, 33(1), 154-170.

Schultz, P. W., Nolan, J. M., Cialdini, R. B., Goldstein, N. J., \& Griskevicius, V. (2007). The Constructive, Destructive, and Reconstructive Power of Social Norms. Psychological Science, 18(5), 429-434.

Stewart, R. (2006). Instrument Choice. In D. Bodansky, J. Brunnée \& E. Hey (Eds.), The Oxford Handbook of Environmental Law (pp. 147-181). Oxford: Oxford University Press.

Ten Heuvelhof, E., de Jong, M., Kars, M., \& Stout, H. (2009). Strategic Behaviour in Network Industries. Cheltenham: Edward Elgar.

Thomas, I. G. (2010). Environmental policy and local government in Australia. Local Environment, 15(2), 121-136.

Van Bueren, E., \& Priemus, H. (2002). Institutional barriers to sustainable construction. Environment and Planning B, 29(1), 75-86.

Van der Heijden, J. (2012). Voluntary Environmental Governance Arrangements. Environmental Policies, 21(3), 486-509.

Van der Heijden, J., \& De Jong, J. (2009). Towards a better understanding of building regulation. Environment and planning B, Planning \& Design, 36(6), 1038-1052.

Vinagre Diaz, J. J., Wilby, M. R., \& Belén Rodríguez González, A. (2013). Setting up GHGbased energy efficiency targets in buildings: The Ecolabel. Energy Policy, 59(C), 633-642.

Wurzel, R., Zito, A., \& Jordan, A. (2013). Environmental Governance in Europe. Cheltenham: Edward Elgar.

Yudelson, J. (2009). Green Building Trends. Europe. Washington: Island Press.

Zito, A., Bruckner, L., Jordan, A., \& Wurzel, R. (2003). Instrument Innovation in an Environmental Lead State. Environmental Politics, 12(1), 157-178. 